\title{
Total Synthesis and Allelopathic Activity of Cytosporones A-C
}

\author{
Charles E. M. Zamberlam, ${ }^{a}$ Alisson Meza, ${ }^{a}$ Carla Braga Leite, ${ }^{b}$ Maria Rita Marques, ${ }^{b}$ \\ Dênis P. de Lima and Adilson Beatriz ${ }^{*}, a$
}

\author{
${ }^{a}$ Centro de Ciências Exatas e Tecnologia, Universidade Federal de Mato Grosso do Sul, \\ Av. Senador Filinto Müller, 1555, 79074-460 Campo Grande-MS, Brazil \\ ${ }^{b}$ Centro de Ciências Biológicas e da Saúde, Universidade Federal de Mato Grosso do Sul, \\ Cidade Universitária s/n, 79070-900 Campo Grande-MS, Brazil
}

\begin{abstract}
A busca por herbicidas eficientes e ambientalmente corretos tem sido foco de numerosos estudos sobre a síntese de compostos isolados de fontes naturais. Citosporonas, as quais são lipídeos fenólicos isolados de fungos, apresentam notáveis propriedades biológicas. Este artigo relata a preparação das citosporonas A, B e C, através de uma rota sintética curta e com excelentes rendimentos. Os compostos sintetizados foram avaliados quanto às suas atividades alelopáticas em sementes de alface (Lactuca sativa $\mathrm{L}$ ). Citosporona A e seu precursor metilado mostraram notável atividade alelopática, inibindo a germinação de sementes e crescimento das plântulas.
\end{abstract}

The search for efficient, environmentally friendly herbicides has been the focus of numerous studies on the organic synthesis of compounds isolated from natural sources. Cytosporones, which are phenolic lipids isolated from fungi, exhibit noteworthy biological properties. This paper reports the preparation of cytosporones A-C from the same starting material through a short synthetic route, with good yields. All compounds were tested for allelopathic activity on lettuce (Lactuca sativa $\mathrm{L}$ ) seeds. Cytosporone A and its methylated precursor showed remarkable allelopathic activity, inhibiting seed germination and plantule growth.

Keywords: cytosporones, phenolic compounds, allelopathy, herbicides, Friedel-Crafts reaction

\section{Introduction}

Phenolic compounds with long hydrophobic side chains have been isolated as secondary metabolites from plants, fungi, and bacteria since the beginning of the $20^{\text {th }}$ century. Within the plant kingdom, these natural amphiphilic compounds, termed phenolic lipids, can be found in the Gramineae, Leguminosae, and Anacardiaceae. Resorcinolic lipids and their derivatives have drawn the interest of researchers, given their range of biological properties, which allows these compounds to be used as antibiotic, antifungal, molluscicidal, antitumoral, antiparasitic, and antioxidant agents. ${ }^{1,2}$

In 2000, Brady et al. ${ }^{3}$ isolated five non-isoprenoid octaketide phenolic lipids from the endophytic fungi Cytospora sp. and Diaporthe sp., which were named cytosporones A-E (1-5, Figure 1). Cytosporones D and $\mathrm{E}$ (4 and $\mathbf{5}$ ) exhibited bactericidal activity against

*e-mail: adilson.beatriz@ufms.br
Staphylococcus aureus, Enterococcus faecalis, and Escherichia coli and fungicidal activity against Candida albicans. Cytosporone B (2) was later found to behave as a natural agonist ligand of the orphan nuclear receptor Nur77 of eukaryotic cells, which controls apoptosis in tumor cells and the metabolism of carbohydrates in mammals, properties that make it a potent and selective cytotoxic agent. $^{4}$

Cytosporone A (1), also previously isolated from a phytoparasitic fungus (Phoma sp.), regulates seed germination factors at low concentrations, in addition to having herbicidal potential. ${ }^{5}$

Inhibition of plant growth and development by compounds released in the environment by other plants or microorganisms is known as allelopathy. The term applies both to beneficial or detrimental interactions, involving either direct or indirect mechanisms. Allelochemicals can be released in the substrate or volatilized. ${ }^{6}$ The role of allelopathy in natural environments and agroecosystems has drawn attention to its potential use in weed biological 
<smiles>CCCCCCCC(=O)c1c(O)cc(O)cc1CC(=O)OP</smiles>

$\mathrm{R}=\mathrm{H}$, Cytosporone A (1)

$\mathrm{R}=\mathrm{Et}$, Cytosporone B (2)

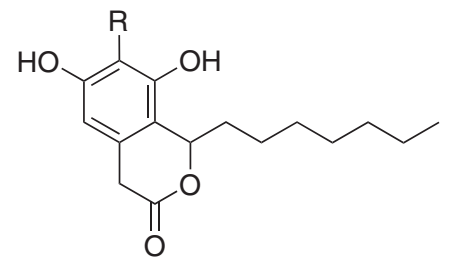

$\mathrm{R}=\mathrm{H}$, Cytosporone $\mathrm{C}$ (3)

$\mathrm{R}=\mathrm{OH}$, Cytosporone $\mathrm{D}(4)$

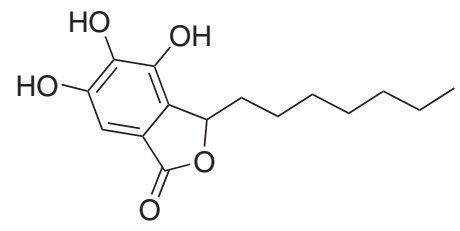

Cytosporone E (5)

Figure 1. Cytosporones A-E.

control. The active participation of researchers from various areas has raised allelopathy to a multidisciplinary field of investigation, leading it to evolve from a basic to an applied science, owing to its applications in agriculture and forestry. ${ }^{7}$

Weeds compete for resources with food cultures, decreasing the productivity of the latter and contaminating subsequent cultivation through seed dispersal. ${ }^{8}$ Of an estimated 7000 weed species, some 200 to 300 are considered pests, because of the considerable losses they inflict on producers, not only lowering productivity, but also increasing costs with herbicides. In 2004, the sector of agrochemicals in Brazil attained record sales, totaling US\$ 4.495 billion. Herbicides alone are responsible for US\$ 1.830 billion in sales, accounting for $54.1 \%$ of the market for agricultural defensives. ${ }^{9}$ In the USA, expenses with herbicides have reached around US\$ 6 billion since the late 1990s, as a consequence of acquired resistance to herbicides in target plant species. In addition, the abuse of synthetic herbicides takes its toll on human, animal and environmental health. ${ }^{8,10,11}$ These concerns are drawing attention to alternative weed control technologies based on natural products. ${ }^{8}$

From an agronomic viewpoint, the research on allelophathy provides perspectives for reduction of the use of traditional herbicides. In a so-called organic production, the herbicides are totally suppressed and replaced by allelophatic compounds or extracts whose action mechanisms are generally very different. ${ }^{12}$ Furthermore, the majority of allelophathic compounds are biodegradable and less poluents than the traditional herbicides. ${ }^{13}$

Herbicides based on natural products have demonstrated advantages over their classic counterparts, with lower ecological impact. Synthetic derivatives or semisynthetic compounds of these natural products can be more active, more selective, and longer-lasting agrochemicals. By acting through a different mechanism than conventional herbicides, many allelochemichals are a good choice as lead compounds to guide the discovery of new herbicides. ${ }^{8}$ Besides, the continuing search for new agrochemical products has demonstrated that natural selection has been superior to combinatorial chemistry in developing bioactive compounds with varied biological activities. ${ }^{14}$ These possibilities led our research group to focus on the development of new herbicides based on natural products obtained from microbial sources, and we have recently reported the synthesis of cytosporone analogues with promising allelopathic activity. ${ }^{15}$ In the present article, we report the total synthesis of cytosporones A (1), B (2), and C (3) through a short, high-yield synthetic route. All natural products and intermediates involved were tested for their potential inhibition of seed germination and plantule development of lettuce (Lactuca sativa L., cv. Grand Rapids - Asteraceae).

\section{Results and Discussion}

\section{Synthesis}

Employing retrosynthetic analysis (Scheme 1), cytosporones A-C can be prepared through a single connection, followed by FGIs. 3,5-Dimethoxybenzoic acid (7) is commercially available at low cost. However, an additional step is required to homologate the carbon chain. For this purpose, phenylacetic acid $\mathbf{6}$ would be a more reliable (albeit more costly) reagent, allowing the reconnection of 6 with 9 to yield the advanced intermediate 8. The subsequent steps would consist of simple FGIs leading to formation of target compounds.

Scheme 2 shows the sequence of reactions selected for direct synthesis of compounds $\mathbf{1}, \mathbf{2}$, and $\mathbf{3}$, involving Friedel-Crafts acylation to form a C-C bond between the hydrophobic pendant and the hydrophilic aromatic ring. 3,5-Dimethoxyphenylacetic acid (6), used as the starting material, underwent acylation with octanoyl chloride in $\mathrm{CH}_{2} \mathrm{Cl}_{2}$ under reflux in the presence of $\mathrm{AlCl}_{3}$ as the catalyst, giving the intermediate product 2-octanoyl-3,5dimethoxyphenyl acetic acid (8), with $90 \%$ yield, and compound 10 , with $5 \%$ yield. The ${ }^{1} \mathrm{H}$ NMR spectrum of 8 showed one triplet at $\delta_{\mathrm{H}} 2.93 \mathrm{ppm}(2 \mathrm{H}, J 7.0 \mathrm{~Hz})$, which typically indicates homotopic methylenic hydrogens adjacent to the carbonyl of a ketone; two doublets at 
<smiles>CCCCCCCC(=O)c1c(O)cc(O)cc1COCC</smiles><smiles>C=CC=CC</smiles><smiles>C=CCOC(=O)c1c(O)cc(O)cc1C(=O)O</smiles><smiles>C=CC=CC(=O)OCc1cc(OC)cc(OC)c1C(=O)CCCCCC</smiles><smiles>CCCCCCCC1OC(=O)Cc2cc(O)cc(O)c21</smiles><smiles>[X]C(=O)CCCCCCC</smiles>
6, $\mathrm{n}=1$ $7, \mathrm{n}=0$

Scheme 1. Retrosynthetic analysis of cytosporones A-C.
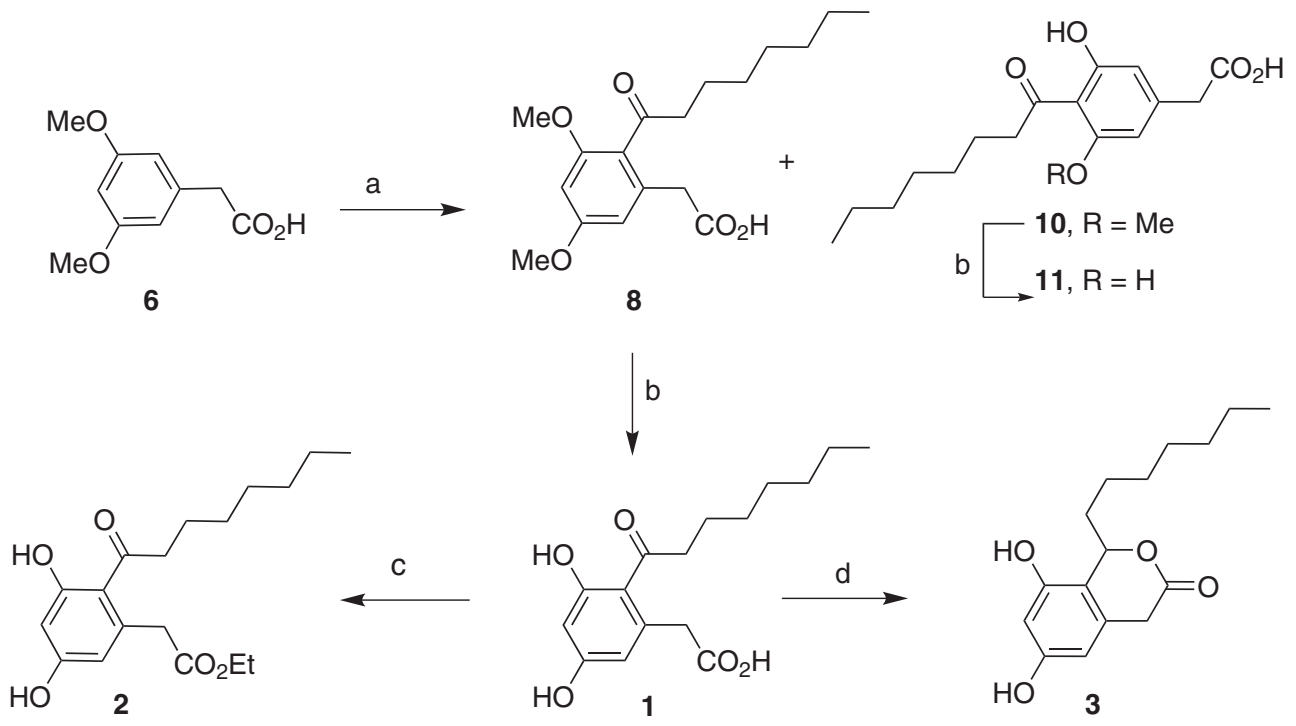

Scheme 2. Synthetic route to cytosporones A (1), B (2) and C (3). a) $\mathrm{Me}\left(\mathrm{CH}_{2}\right)_{6} \mathrm{COCl}, \mathrm{AlCl}_{3}, \mathrm{CH}_{2} \mathrm{Cl}_{2} ;$ b) $\mathrm{AlCl}_{3}$, toluene; c) ethanol, $\left.\mathrm{H}_{2} \mathrm{SO}_{4} ; \mathrm{d}\right) \mathrm{NaBH}_{4}$, ethanol.

$\delta_{\mathrm{H}} 6.50 \mathrm{ppm}(1 \mathrm{H})$ and $6.43 \mathrm{ppm}(1 \mathrm{H}), J 2.0 \mathrm{~Hz}$, which is consistent with aromatic hydrogens having a meta relationship. ${ }^{13} \mathrm{C}$ chemical shift and ${ }^{1} \mathrm{H}-{ }^{13} \mathrm{C}$ DEPT NMR data confirmed the presence of 3 methyl, 7 methylene, 6 aromatic, 1 carboxyl carbon (at $172.3 \mathrm{ppm}$ ), and 1 carbonyl carbon atom (at $210.1 \mathrm{ppm}$ ). The transformation of the compound $\mathbf{8}$ to the known cytosporone A (1), discussed below, confirmed its structure.

The ${ }^{1} \mathrm{H}$ NMR spectra of $\mathbf{1 0}$ had two aromatic hydrogen signals, at $\delta_{\mathrm{H}} 6.50(\mathrm{~d}, 1 \mathrm{H}) \mathrm{ppm}$ and $6.30 \mathrm{ppm}(\mathrm{d}, 1 \mathrm{H})$, $J 2.0 \mathrm{~Hz}$; a singlet at $\delta_{\mathrm{H}} 13.35 \mathrm{ppm}(1 \mathrm{H})$, assigned to a phenolic hydroxyl in a hydrogen bond, and a singlet at $\delta_{\mathrm{H}} 3.87 \mathrm{ppm}(3 \mathrm{H})$, in the region of aromatic methoxyls. The ${ }^{13} \mathrm{C}$ NMR spectra exhibited a signal at $\delta_{\mathrm{C}} 207.6 \mathrm{ppm}$ (C), related to a ketone carbonyl, and one single signal at $\delta_{\mathrm{C}} 55.7 \mathrm{ppm}\left(\mathrm{OCH}_{3}\right)$. The presence of a phenolic hydroxyl in 10 is explained by the action of $\mathrm{AlCl}_{3}$, which is a phenolic deprotection agent. Two-dimensional NMR experiments (HMBC, HSQC, and NOESY) corroborated the structure assignment of compound 10. $O$-Demethylation of $\mathbf{1 0}$ using $\mathrm{AlCl}_{3}$ in toluene under reflux furnished $60 \%$ yield of the regioisomer of cytosporone A (11). 
Compound $\mathbf{8}$ was subsequently demethylated using $\mathrm{AlCl}_{3}$ in toluene under reflux, to give cytosporone A (1) with a good yield (90\%). Cytosporone A tautomerism, reported by Voblikova et al., ${ }^{5}$ was not detected in the ${ }^{1} \mathrm{H}$ NMR spectra using deuterated methanol as the solvent. Cytosporone B (2) was obtained in a quantitative yield from 1 after esterification in acid medium with ethanol. Reduction of cytosporone A (1) by $\mathrm{NaBH}_{4}$ in ethanol was the method selected to produce cytosporone $\mathrm{C}(\mathbf{3})$. After this reaction, cyclization of the resulting alcohol produced the formation of the six-membered ring lactone, in $90 \%$ yield. Characterization data of cytosporones A-C were in complete agreement with the literature data reported by Brady et al. ${ }^{3}$

The total syntheses of cytosporones $\mathrm{A}$ and $\mathrm{C}$ have not been reported in the literature. As for cytosporone $\mathrm{B}$, the synthesis was recently reported by Huang et al. ${ }^{16}$ in a $44 \%$ global yield. The authors have prepared the intermediate 12 (Scheme 3) by esterification of the corresponding acid 6 followed by Friedel-Crafts reaction to connect the acyl group to the aromatic ring. However, since the deprotection procedures using $\mathrm{BBr}_{3}, \mathrm{HBr} / \mathrm{AcOH}$ and $\mathrm{AlCl}_{3}$ were unsuccessful, a sequence of protection and deprotection reactions was carried out, increasing the synthetic route in three more steps.

In our procedure, the key step of demethylation of carboxylic acid $\mathbf{8}$ was performed by using $\mathrm{AlCl}_{3}$ in toluene under reflux, outperforming the previously reported synthesis, where the same transformation was attempted in $\mathrm{CH}_{2} \mathrm{Cl}_{2}$ at $0^{\circ} \mathrm{C}$ to r.t. In conclusion, by using our procedure, it is possible to achieve cytosporone B with $81 \%$ global yield from the same starting material (compound 6).

\section{Allelopathy}

Allelochemical compounds modify plant physiological processes by acting as germination and growth inhibitors. The visible effect is only a secondary sign of the action of these compounds on germination and development, an action initially taking place at the molecular and cellular levels, involving a great number of molecules and plant hormones. ${ }^{17,18}$
Most of the known allelochemicals are secondary metabolites and multifunctional compounds. ${ }^{19}$ Therefore, many studies are being carried out with organic solvents to extract pure bioactive compounds or for their homogeneization. ${ }^{20,21}$ These in vitro assays are considered a first investigation approach of the allelophathic potential, following by tests in field or semi-field conditions, by using different types of formulations. ${ }^{22}$ Among the widely accepted methods to test allelophathy reported in the literature, there are those on lettuce (Lactuca sativa) seeds since they are characterized by homogeneous germination and, are easy to manipulate. Providing the controls are correctly prepared, the results are recognized as a positive indication of allelophatic activity in tested extracts or pure compounds. ${ }^{19,23}$

The synthesized compounds $\mathbf{8}, \mathbf{1}, \mathbf{2}$, and $\mathbf{3}$ were submitted to allelopathic assays on seeds of $L$. sativa ${ }^{24}$ to evaluate inhibition of germination. The assay also served to evaluate the ability of these compounds to inhibit the development of hypocotyls and primary roots of $L$. sativa seedlings. Caffeine was used as a positive control because of its known inhibitory activity on seed germination and seedling growth. The negative controls were a buffer solution and the solvents (chloroform for compound $\mathbf{8}$ and methanol for the others) employed in the experiment.

The germination rates are shown in Table 1. A previous experiment carried out at a concentration of $5 \mathrm{mg} \mathrm{mL}^{-1}$ to determine the allelopathic profile did not provide evidence of germination for three days, except when cytosporone C (3) was employed. Subsequently, the experiment was repeated at concentrations of 2.5 and $1.25 \mathrm{mg} \mathrm{mL}^{-1}$, revealing satisfactory allelopathic activity for $\mathbf{1}$ and $\mathbf{8}$, allowing these compounds to be further diluted to $0.625 \mathrm{mg} \mathrm{mL}^{-1}$.

Cytosporone $\mathrm{C}(\mathbf{3})$ exhibited lower inhibitory activity than the other compounds or caffeine. Cytosporone A (1) and its precursor (8) fully inhibited seed germination at $2.5 \mathrm{mg} \mathrm{mL}^{-1}$ for three days. Also, $\mathbf{1}$ and $\mathbf{8}$ were more active than caffeine at this concentration. At $1.25 \mathrm{mg} \mathrm{mL}^{-1}$, cytosporone A (1) inhibited nearly all the seeds for the first day and was slightly inferior to compound $\mathbf{8}$ for the last

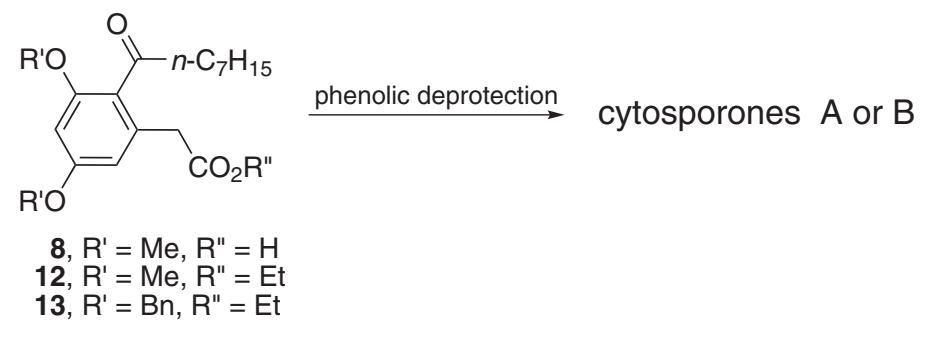


Table 1. Percentage of germination inhibition of $L$. sativa seeds for selected compounds over a three-day period

\begin{tabular}{|c|c|c|c|c|c|}
\hline \multirow{3}{*}{ Concentration / $\left(\mathrm{mg} \mathrm{mL}^{-1}\right)$} & \multicolumn{5}{|c|}{ Percentage of inhibition } \\
\hline & \multirow{2}{*}{ Caffeine } & \multicolumn{4}{|c|}{ Compounds } \\
\hline & & 8 & 1 & 2 & 3 \\
\hline 2.5 & $\begin{array}{c}\mathrm{d} 1=100 \\
\mathrm{~d} 2=67 \pm 10 \\
\mathrm{~d} 3=52 \pm 8\end{array}$ & $\begin{array}{l}\mathrm{d} 1=100 \\
\mathrm{~d} 2=100 \\
\mathrm{~d} 3=100\end{array}$ & $\begin{array}{l}\mathrm{d} 1=100 \\
\mathrm{~d} 2=100 \\
\mathrm{~d} 3=100\end{array}$ & $\begin{array}{l}\mathrm{d} 1=99 \pm 23 \\
\mathrm{~d} 2=49 \pm 18 \\
\mathrm{~d} 3=38 \pm 16\end{array}$ & $\begin{array}{l}\mathrm{d} 1=76 \pm 7 \\
\mathrm{~d} 2=36 \pm 2 \\
\mathrm{~d} 3=25 \pm 6\end{array}$ \\
\hline 1.25 & $\begin{array}{c}\mathrm{d} 1=87 \pm 9 \\
\mathrm{~d} 2=45 \pm 10 \\
\mathrm{~d} 3=32 \pm 18\end{array}$ & $\begin{array}{l}\mathrm{d} 1=69 \pm 16 \\
\mathrm{~d} 2=71 \pm 30 \\
\mathrm{~d} 3=63 \pm 25\end{array}$ & $\begin{array}{c}\mathrm{d} 1=92 \pm 4 \\
\mathrm{~d} 2=55 \pm 10 \\
\mathrm{~d} 3=49 \pm 4\end{array}$ & $\begin{array}{c}\mathrm{d} 1=84 \pm 23 \\
\mathrm{~d} 2=42 \pm 10 \\
\mathrm{~d} 3=34 \pm 7\end{array}$ & $\begin{array}{l}\mathrm{d} 1=77 \pm 7 \\
\mathrm{~d} 2=34 \pm 8 \\
\mathrm{~d} 3=25 \pm 9\end{array}$ \\
\hline 0.625 & $\begin{array}{c}\mathrm{d} 1=79 \pm 15 \\
\mathrm{~d} 2=42 \pm 2 \\
\mathrm{~d} 3=25 \pm 7\end{array}$ & $\begin{array}{c}\mathrm{d} 1=57 \pm 14 \\
\mathrm{~d} 2=42 \pm 12 \\
\mathrm{~d} 3=32 \pm 8\end{array}$ & $\begin{array}{l}\mathrm{d} 1=85 \pm 3 \\
\mathrm{~d} 2=46 \pm 4 \\
\mathrm{~d} 3=32 \pm 7\end{array}$ & - & - \\
\hline
\end{tabular}

$\mathrm{d} 1$ : day $1 ; \mathrm{d} 2$ : day $2 ; \mathrm{d} 3$ : day 3 . Inhibition by buffer solution $(\%)$ : $\mathrm{d} 1=39 \pm 12 ; \mathrm{d} 2=25 \pm 7 ; \mathrm{d} 3=8 \pm 5$. Inhibition by solvent $(\%)$ : $\mathrm{d} 1=40 \pm 4 ; \mathrm{d} 2=23 \pm 6$; $\mathrm{d} 3=17 \pm 8$.

two days. Both $\mathbf{1}$ and $\mathbf{8}$, however, were more active than caffeine. At the lowest concentration $\left(0.625 \mathrm{mg} \mathrm{mL}^{-1}\right)$, these compounds inhibited germination more strongly than caffeine or the other compounds evaluated. At this concentration, cytosporone A (1) yielded superior results. Cytosporone B (2) showed reasonable inhibition ability, similar to that of caffeine.

On the fifth day of the experiment, hypocotyl and primary root length were measured in the surviving seedlings (Table 2). Primary root length was the feature most visibly affected by all compounds.

Table 2. Average length of primary root and hypocotyl in germinating seeds of $L$. sativa after treatment with synthesized compounds

\begin{tabular}{lccc}
\hline \multirow{2}{*}{ Sample } & $\begin{array}{c}\text { Concentration } / \\
\left(\mathrm{mg} \mathrm{mL}^{-1}\right)\end{array}$ & \multicolumn{2}{c}{ Average length / mm } \\
\cline { 2 - 4 } Buffer & - & $14.4( \pm 1.4)$ & $4.0( \pm 2.5)$ \\
Chloroform & - & $11.5( \pm 2.1)$ & $4.2( \pm 1.4)$ \\
Methanol & - & $17.2( \pm 3.5)$ & $3.8( \pm 3.4)$ \\
Caffeine & 2.5 & $1.0( \pm 0.1)$ & $1.4( \pm 0.2)$ \\
& 1.25 & $0.4( \pm 0.2)$ & $2.4( \pm 0.8)$ \\
& 0.625 & $1.2( \pm 0.8)$ & $2.4( \pm 0.1)$ \\
$\mathbf{8}$ & 2.5 & 0 & 0 \\
& 1.25 & $0.6( \pm 1.6)$ & $0.4( \pm 0.8)$ \\
$\mathbf{1}$ & 0.625 & $6.0( \pm 1.8)$ & $2.4( \pm 0.4)$ \\
& 2.5 & 0 & 0 \\
& 1.25 & $0.5( \pm 0.1)$ & $0.8( \pm 0.2)$ \\
$\mathbf{2}$ & 0.625 & $2.0( \pm 0.2)$ & $2.5( \pm 0.1)$ \\
& 2.5 & $0.8( \pm 0.2)$ & $1.8( \pm 0.1)$ \\
$\mathbf{3}$ & 1.25 & $1( \pm 0.2)$ & $2.4( \pm 0.5)$ \\
& 2.5 & $1.4( \pm 2.4)$ & $6.8( \pm 3.1)$ \\
& 1.25 & $3.5( \pm 1.3)$ & $7.2( \pm 1.4)$ \\
\hline
\end{tabular}

Inhibition by chloroform $(\%)$ : $\mathrm{d} 1=40( \pm 4)$; $\mathrm{d} 2=23( \pm 6)$; $\mathrm{d} 3=17( \pm 8)$. Inhibition by methanol $(\%): \mathrm{d} 1=40( \pm 4) ; \mathrm{d} 2=23( \pm 6) ; \mathrm{d} 3=17( \pm 8)$.
Cytosporone C (3) interfered the least in initial tissue development of the seeds, but retarded primary root growth.

Of the compounds tested, cytosporone A (1) showed the best results, inhibiting $100 \%$ of seed germination at a concentration of $2.5 \mathrm{mg} \mathrm{mL}^{-1}$ and drastically reducing primary root and hypocotyl growth at the evaluated concentrations (see Table 2). It also inhibited primary root development substantially more than caffeine, while its inhibiting effect on hypocotyl development was similar to that of caffeine.

Cytosporone B (2) also effectively inhibited seedling growth, to a similar degree as caffeine, but less strongly than cytosporone A (1) or its synthetic precursor (8). The latter failed to effectively inhibit primary root growth at a concentration of $0.625 \mathrm{mg} \mathrm{mL}^{-1}$.

The results of seedling growth inhibition demonstrate the allelopathic properties of cytosporone A (1), its synthetic precursor (8), and cytosporone B (2).

The literature reports that phenolic compounds, especially phenolic acids, originating from the shikimic acid and polyketide routes, are potentially allelopathic. In natural environments and agroecosystems, these secondary metabolites interfere with growth and development of other plant species. ${ }^{25,26}$ Cytosporones are generated through the same biosynthetic route as other phenolic lipids. ${ }^{1,3}$ Their production by endophytic fungi is an aspect of the mutualistic interaction between these organisms and some plant species. Secondary compounds released in the environment by fungi can improve survival resources that allow plants to compete with other species. Phenolic compounds are also found in pre-cultivated soils of this class of compounds. These soils show allelopathic activity, probably indicating cumulative dispersal of phenols to the environment. ${ }^{27}$

Porter and Thimann ${ }^{28}$ reported that some organic acids whose structures include a charge separation of 
approximately $0.5 \mathrm{~nm}$ exhibit allelopathic activity, manifested as seed germination inhibition. These compounds include indoleacetic acid, phenylacetic acid, and the agrochemical 2,4-D (Figure 2). The same feature is found in the structure of cytosporone A (1) and its synthetic methylated precursor $(\mathbf{8})$, allowing us to infer that this condition limits a more pronounced inhibitory activity on lettuce seeds by either compound. This ionic separation is not found in the structures of cytosporones B (2) or $\mathrm{C}(\mathbf{3})$, in which the acid group is esterified. The lactone ester renders cytosporone $\mathrm{C}(\mathbf{3})$ structurally more rigid in comparison to cytosporone B (2), suggesting substantial loss of activity in $\mathbf{3}$.
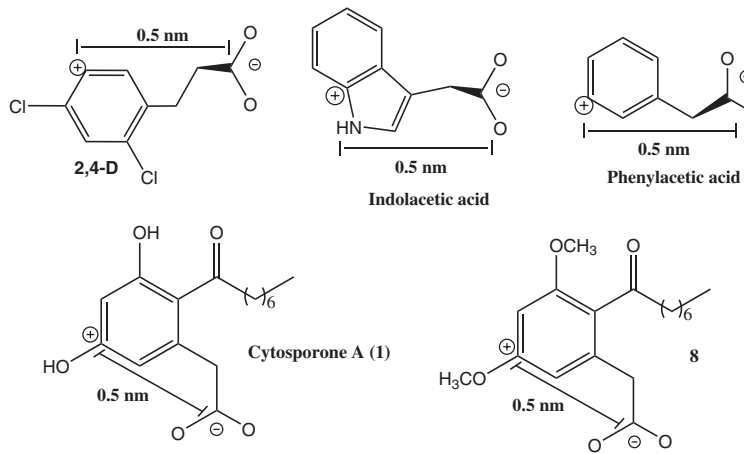

Figure 2. Structural separation of charges in allelochemicals.

\section{Experimental}

\section{General}

${ }^{1} \mathrm{H}$ and ${ }^{13} \mathrm{C}$ NMR spectra were obtained at 300 and $75 \mathrm{MHz}$, respectively, using a Bruker Avance DPX-300 spectrometer. Chemical shifts are reported relative to TMS; coupling constants are given in hertz. IR spectra were recorded on a Bomen FT-IR-MB100 Spectrometer. Mass spectra (EI, $70 \mathrm{eV}$ ) were run on a Shimadzu CGMS QP2010 Plus gas chromatography mass spectrometer. Melting points were measured by a Uniscience do Brasil 498 apparatus. Purifications were carried out by means of flash chromatography using silica from Merck. All compounds and reagents were commercially acquired from Acros, Synth, and Merck. The allelopathy experiment was performed in BOD chambers (model MA 415/S Marconi).

\section{Synthesis}

\section{3,5-Dimethoxy-2-octanoylphenylacetic acid (8)}

Thionyl chloride $(0.17 \mathrm{~mL}, 2.3 \mathrm{mmol})$ was added to a solution of octanoic acid $(0.17 \mathrm{~g}, 1.2 \mathrm{mmol})$ in $\mathrm{CH}_{2} \mathrm{Cl}_{2}$ $(3.5 \mathrm{~mL})$ under nitrogen atmosphere. After reflux under stirring for $4 \mathrm{~h}$, the solvent was evaporated by vacuum pump, followed by addition of dry $\mathrm{CH}_{2} \mathrm{Cl}_{2}(4.4 \mathrm{~mL})$. The resulting solution was added dropwise to a solution of 3,5-dimethoxyphenylacetic acid (6) $(0.15 \mathrm{~g}, 0.8 \mathrm{mmol})$ in $\mathrm{CH}_{2} \mathrm{Cl}_{2}(4 \mathrm{~mL})$ under a nitrogen atmosphere in a crushedice bath. After complete addition of octanoyl chloride, the reaction was kept under reflux for $6 \mathrm{~h}$. A solution of aqueous $\mathrm{HCl} 6 \mathrm{~mol} \mathrm{~L}^{-1}(20 \mathrm{~mL})$ was added to the reaction mixture, transferred to a separatory funnel, and extracted with ethyl acetate $(3 \times 20 \mathrm{~mL})$. The organic phase was dried over $\mathrm{MgSO}_{4}$ and filtered, and the solvent removed under reduced pressure. Products $\mathbf{8}$ and $\mathbf{1 0}$ and the starting material were purified by column chromatography (6:3:1, hexane:ethyl acetate: $\mathrm{CH}_{2} \mathrm{Cl}_{2}$ ). Product 8 (90\% yield) is a white solid, $\mathrm{mp}$ 72-78 ${ }^{\circ} \mathrm{C}$ (recrystallized from $\mathrm{CHCl}_{3}$ ). Compound $\mathbf{1 0}$ (5\% yield) is a white solid, mp $122-126^{\circ} \mathrm{C}$.

\section{3,5-Dihydroxy-4-octanoylbenzoic acid (11)}

A solution of compound $\mathbf{1 0}(0.04 \mathrm{~g}, 0.14 \mathrm{mmol})$ in toluene $(15 \mathrm{~mL})$ was added to a two-necked round bottom flask attached to a condenser connected to a silica gel drying tube. Next, dry $\mathrm{AlCl}_{3}(0.26 \mathrm{~g}, 2.0 \mathrm{mmol})$ was added and the reaction was stirred and refluxed for $7 \mathrm{~h}$. Subsequently, a cooled diluted solution of $\mathrm{HCl} 1 \mathrm{~mol} \mathrm{~L}^{-1}(5 \mathrm{~mL})$ was added dropwise. The reaction mixture was extracted with ethyl acetate $(3 \times 30 \mathrm{~mL})$, washed with brine, and dried over $\mathrm{MgSO}_{4}$. The product was purified by flash chromatography on silica gel (1:1, hexane:ethyl acetate). Compound $\mathbf{1 1}$ is a white solid (60\% yield), $\mathrm{mp} 73-77^{\circ} \mathrm{C}$ (recrystallized from ethyl acetate).

\section{Cytosporone A (1)}

Compound 8 (0.04 g, $0.12 \mathrm{mmol})$ was solubilized in anhydrous toluene $(10 \mathrm{~mL})$ and the solution was stirred. $\mathrm{AlCl}_{3}$ was added $(0.24 \mathrm{~g}, 1.8 \mathrm{mmol})$ to the solution and the reaction was kept under stirring and reflux for $7 \mathrm{~h}$. After this period, a diluted solution of $\mathrm{HCl} 1 \mathrm{~mol} \mathrm{~L}^{-1}(10 \mathrm{~mL})$ was added. The reaction mixture was placed into a separatory funnel and extracted with ethyl acetate $(3 \times 20 \mathrm{~mL})$. The organic phase was washed with brine, dried over $\mathrm{MgSO}_{4}$ $(3 \times 20 \mathrm{~mL})$, filtered, and the solvent was evaporated under reduced pressure. The product was purified by flash chromatography (1:1, hexane:ethyl acetate). Cytosporone A (1) was obtained as a white solid (90\% yield); $\mathrm{mp} 109-113^{\circ} \mathrm{C}$ (recrystallized from ethyl acetate).

\section{Cytosporone B (2)}

An anhydrous ethanol solution $(10 \mathrm{~mL})$ of cytosporone A (1) $(0.02 \mathrm{~g}, 0.07 \mathrm{mmol})$ was prepared. $0.05 \mathrm{~mL}$ of concentrated sulfuric acid was added to this solution, and the reaction was kept under stirring for $1 \mathrm{~h}$ at room 
temperature. After this period, $\mathrm{CH}_{2} \mathrm{Cl}_{2}(20 \mathrm{~mL})$ was added and the organic phase was washed with a diluted solution of $\mathrm{NaHCO}_{3}(4 \times 10 \mathrm{~mL})$, dried over $\mathrm{MgSO}_{4}$ and filtered, and the solvent was evaporated under reduced pressure. Cytosporone B was obtained as a brown solid (95\% yield); mp 35- $40{ }^{\circ} \mathrm{C}$ (recrystallized from $\mathrm{CHCl}_{3}$ ).

\section{Cytosporone C (3)}

A solution of $1(0.01 \mathrm{~g}, 0.034 \mathrm{mmol})$ and $\mathrm{NaBH}_{4}$ $(0.003 \mathrm{~g}, 0.06 \mathrm{mmol})$ in anhydrous ethanol $(5 \mathrm{~mL})$ was stirred at room temperature for $24 \mathrm{~h}$. Next, about $0.15 \mathrm{~mL}$ of concentrated $\mathrm{HCl}$ and distilled water $(10 \mathrm{~mL})$ were added. The mixture was placed in a separatory funnel and the product was extracted with ethyl acetate $(2 \times 20 \mathrm{~mL})$. The organic phase was dried over $\mathrm{MgSO}_{4}$, filtered, and the solvent was evaporated under reduced pressure. The product was purified by flash chromatography $(2: 1$, hexane:ethyl acetate). Cytosporone C (3) was obtained as colorless oil (90\%).

\section{Allelopathy assay}

The methodology applied is reported in the literature with modifications. ${ }^{24}$ Filter papers, previously wet with the test solutions at selected concentrations (Table 1), were placed into Petri dishes. Solutions of caffeine at the same concentrations, also placed on filter papers, served as positive controls. Negative controls comprised of one filter paper wet with the solvent used (chloroform and methanol) and one with the buffer solution employed in the experiment. The Petri dishes were maintained at $45^{\circ} \mathrm{C}$, for $1 \mathrm{~h}$, to evaporate the solvent, at a mild temperature, in order to keep the properties of the tested compounds. Next, 25 seeds of $L$. sativa were placed on each dish and wet with a solution of phosphate buffer $\left(0.025 \mathrm{~mol} \mathrm{~L}^{-1} \mathrm{pH}\right.$ 6.0) (day 0 ). The experiment was conducted in a chamber at $25^{\circ} \mathrm{C} \pm 2{ }^{\circ} \mathrm{C}$ with a photoperiod of $12 \mathrm{~h}$ for three days. The assay was carried out in triplicate and the number of germinated seeds from day 1 to day 3 was counted by sampling. Seeds exhibiting radicle protrusion greater than or equal to $2 \mathrm{~mm}$ were considered germinated. The total number of non-germinated seeds was expressed as percentage of inhibition.

\section{Conclusions}

In summary, the total synthesis of cytosporones A-C has been achieved from same starting material (3,5-dimethoxyphenylacetic acid) through a short synthetic route, with good yields. The cytosporones and their intermediates were tested for allelopathic activity on lettuce (Lactuca sativa) seeds. Our results revealed that inhibitory allelopathic activity is considerably more pronounced in cytosporone A (1) and its precursor (8), followed by cytosporone B (2), indicating the potential of these compounds as herbicides and as templates for new defensives. Although the other synthesized natural products evaluated did not exhibit comparable allelopathic activity, their synthetic routes (Scheme 2) can feasibly be applied to the industrial development of this class of products, particularly in the case of cytosporone B (2), which can be of pharmaceutical interest.

\section{Supplementary Information}

Analytical data and selected ${ }^{1} \mathrm{H}$ NMR spectra of compounds 1-3 (cytosporones A-C), 8, 10 and $\mathbf{1 1}$ are available free of charge at http://jbcs.sbq.org.br.

\section{Acknowledgments}

The authors would like to thank Kardol Ind. Química Ltda., Fundação de Apoio ao Desenvolvimento do Ensino, Ciência e Tecnologia do Estado de Mato Grosso do Sul (FUNDECT) and CNPq (Brazil) for their financial support. They are also indebted to the UFMS technicians who participated in the experiments.

\section{References}

1. Kozubek, A.; Tyman, J. H. P.; J. Am. Chem. Soc. 1999, 99, 1.

2. Zarnowski, R.; Suzuki, Y.; J. Food Compos. Anal. 2004, 17, 649.

3. Brady, S. F.; Wagenaar, M. M.; Singh, M. P.; Janso, J. E.; Clardy, J.; Org. Lett. 2000, $2,4043$.

4. Zhan, Y.; Du, Xi.; Chen, H.; Liu, J.; Zhao, B.; Huang, D.; Li, G.; Xu, Q.; Zhang, M.; Weimer, B. C.; Chen, D.; Cheng, Z.; Zhang, L.; Li, Q.; Li, S.; Zheng, Z.; Song, S.; Huang, Y.; Ye, Z.; Su, W.; Lin, S. C.; Shen, Y.;Wu, Q.; Nat. Chem. Biol. 2008, 4,548 .

5. Voblikova, V. D.; Kobrina, N. S.; Gerasimova, N. M.; Pavlova, Z. N.; Dem'yanova, G. F.; Murygina,V. P.; Volosova, L. I.; Muromtsev, G. S.; Chem. Nat. Comp. 1985, 21, 362.

6. Rizvi, S. J. H.; Haque, H.; Singh, U. K.; Rizvi, V. A. A. In Allelopathy: Basics and Applied Aspects; Rizvi, S. J. H.; Rizvi, H., eds.; Chapman \& Hall: London, 1992, pp. 1-10.

7. Weston, L. A.; HortTechnology 2005, 15, 529.

8. Vyvyan, J. R; Tetrahedron 2002, 58, 1631.

9. http://www.iea.sp.gov.br/out/index.php, accessed in June 2010.

10. Macías, F. A.; Marín, D.; Oliveros-Bastidas, A.; Varela, R. M.; Simonet, A. M.; Carrera, C.; Molinillo, J. M. G.; Biol. Sci. Space 2003, 17, 18 . 
11. Macías, F. A.; Marín, D.; Oliveros-Bastidas, A.; Chinchilla, D.; Simonet, A. M.; Molinillo, J. M. G.; J. Agric. Food Chem. 2006, 54, 991.

12. Wink, M.; Latz-Bruning, B.; In Allelopathy: Organisms, Processes and Applications; Inderjit, S.; Dakshini, K. M. M.; Einhellig, F. A., eds.; American Chemical Society: Washington DC, 1995, pp. 117-126.

13. Macías, F. A.; Varela, R. M.; Torres, A.; Oliva, R. M.; Molinillo, J. M. G.; Phytochemistry 1998, 48, 631.

14. Gary, A.; Microb. Infect. 2003, 5, 535.

15. Dos Santos, E. A.; Beatriz, A.; De Lima, D. P.; Marques, M. R.; Leite, C. B.; Quim. Nova 2009, 32, 1856.

16. Huang, H.; Zhang, L.; Zhang, X.; Ji, X.; Ding, X.; Shen, X.; Jiang, H.; Liu, H.; Chin. J. Chem. 2010, 28, 1041.

17. Olofsdotter, M.; Malik, A. U.; Agron. J. 2001, 93, 1.

18. Ferreira, A. G.; Aquila, M. E. A.; Rev. Bras. Fisiol. Veg. 2000, 12, 175.

19. Kruse, M.; Strandberg, M.; Strandberg, B.; Ecological Effects of Allelopathic Plants - a Review, NERI Technical Report No. 315, National Environmental Research Institute: Silkevorb, 2000 .
20. Lobo, L. T.; Castro, K. C. F.; Arruda, M. S. P.; Silva, M. N.; Arruda, A. C.; Müller, A. H.; Arruda, G. M. S. P.; Santos, A. S.; Souza Filho, A. P. S.; Quim Nova 2008, 31, 493.

21. Berger, J.; Schager, M.; Biologia (Bratislava) 2004, 59, 9.

22. Olofsdotter, M.; Navarez, D.; Rebulanan, M.; Streibig, J. C.; Weed Res. 1999, 39, 441.

23. Narwal, S. S.; Sampietro, D. A.; Catalán, C. A. N.; Vattuone, M. A.; Politycka, B.; Plant Bioassays, Studium Press LLC: New Delhi, India, 2009.

24. Macias, F. A.; Varela, R. M.; Torres, A.; Oliva, R. M.; Molinillo, J. M. G.; Phytochemistry 1998, 48, 631.

25. Chon, S. -U.; Jang, H. -G.; Kim, D. K.; Kim, Y. -M.; Boo, H. O.; Kim, Y. J.; Scientia Horticulcurae 2005, 106, 309.

26. Blum, U.; Wentworth, T. R.; Klein, K.; Worsham, A. D.; King, L. D.; Gerig, T. M.; Lyu, S. W.; J. Chem. Ecol. 1991, 17, 1045.

27. Inderjit, S.; Dakshini, K. M. M.; Tropical Agriculture 1998, 75, 396.

28. Porter, W. L.; Thimann, K. V.; Phytochemistry 1965, 4, 229.

Submitted: July 25, 2011

Published online: November 1, 2011 


\title{
Total Synthesis and Allelopathic Activity of Cytosporones A-C
}

\section{Charles E. M. Zamberlam, ${ }^{a}$ Alisson Meza, ${ }^{a}$ Carla Braga Leite, ${ }^{b}$ Maria Rita Marques, ${ }^{b}$ Dênis P. de Lima a and Adilson Beatriz*,a}

\begin{abstract}
${ }^{a}$ Centro de Ciências Exatas e Tecnologia, Universidade Federal de Mato Grosso do Sul, Av. Senador Filinto Müller, 1555, 79074-460 Campo Grande-MS, Brazil

${ }^{b}$ Centro de Ciências Biológicas e da Saúde, Universidade Federal de Mato Grosso do Sul, Cidade Universitária s/n, 79070-900 Campo Grande-MS, Brazil
\end{abstract}

Analytical Data and Selected ${ }^{1} \mathrm{H}$ NMR Spectra of Compounds 1-3 (Cytosporones A-C), 8, 10 and 11

Analytical data

\section{Cytosporone A (1)}

${ }^{1} \mathrm{H}$ NMR (300 MHz, CD $\left.\mathrm{OD}\right): \delta 6.26(\mathrm{~d}, 1 \mathrm{H}, J 2 \mathrm{H})$, 6.22 (d, 1H, J 2 Hz), 3.56 (s, 2H), 2.92 (t, 2H, J 7 Hz), 1.62 (qt, 2H, J $7 \mathrm{~Hz}), 1.27-1.33(\mathrm{~m}, 8 \mathrm{H}), 0.90(\mathrm{t}, 3 \mathrm{H}, J 7 \mathrm{~Hz})$. ${ }^{13} \mathrm{C}$ NMR (75 MHz, CD OD): $\delta 209.7$ (C), $175.4(\mathrm{C}), 161.4$ (C), $159.8(\mathrm{C}), 137.3(\mathrm{C}), 121.4(\mathrm{C}), 111.6(\mathrm{CH}), 102.6$ $(\mathrm{CH}), 45.1\left(\mathrm{CH}_{2}\right), 40.6\left(\mathrm{CH}_{2}\right), 32.9\left(\mathrm{CH}_{2}\right), 30.4\left(\mathrm{CH}_{2}\right)$, $30.3\left(\mathrm{CH}_{2}\right), 25.6\left(\mathrm{CH}_{2}\right), 23.7\left(\mathrm{CH}_{2}\right), 14.4\left(\mathrm{CH}_{3}\right)$. IR $(\mathrm{KBr})$ $v_{\max } / \mathrm{cm}^{-1}: 3394,2954,2923,2854,1650,1593,1110 . \mathrm{MS}$ (m/z): 279, 248, 202, 168, 123 (base peak), 95, 77, 67, 51.

\section{Cytosporone B (2)}

${ }^{1} \mathrm{H}$ NMR (300 MHz, $\left.\mathrm{CDCl}_{3}\right): \delta 6.27(\mathrm{~s}, 1 \mathrm{H}), 6.25$ (s, $1 \mathrm{H}), 4.18$ (q, 2H, J $7 \mathrm{~Hz}), 3.81(\mathrm{~s}, 2 \mathrm{H}), 2.80(\mathrm{t}, 2 \mathrm{H}, J 7 \mathrm{~Hz}$,), $1.66(\mathrm{~m}, 2 \mathrm{H}), 1.23-1.28(\mathrm{~m}, 11 \mathrm{H}), 0.84(\mathrm{t}, 3 \mathrm{H}, J 7 \mathrm{~Hz})$. ${ }^{13} \mathrm{C} \mathrm{NMR}\left(75 \mathrm{MHz}, \mathrm{CDCl}_{3}\right): \delta 216.7(\mathrm{C}), 171.2(\mathrm{C}), 164.5$ (C), $160.2(\mathrm{C}), 136.7(\mathrm{C}), 116.6(\mathrm{C}), 112.5(\mathrm{CH}), 103.2$ $(\mathrm{CH}), 61.6\left(\mathrm{CH}_{2}\right), 43.4\left(\mathrm{CH}_{2}\right), 41.8\left(\mathrm{CH}_{2}\right), 31.7\left(\mathrm{CH}_{2}\right), 29.2$ $\left(\mathrm{CH}_{2}\right), 29.1\left(\mathrm{CH}_{2}\right), 24.3\left(\mathrm{CH}_{2}\right), 22.6\left(\mathrm{CH}_{2}\right), 14.1\left(\mathrm{CH}_{3}\right), 14.0$ $\left(\mathrm{CH}_{3}\right)$. IR $(\mathrm{KBr}) v_{\max } / \mathrm{cm}^{-1}: 3255,2954,2923,2854,1708$, 1612, 1573, 1261, 1157. MS (m/z): $322\left(\mathrm{M}^{++}\right), 277,238$, 223, 195, 187 (base peak), 121, 111, 55, 45.

\section{Cytosporone C (3)}

${ }^{1} \mathrm{H}$ NMR (300 MHz, CD 3 OD): $\delta 6.22(\mathrm{~s}, 1 \mathrm{H}), 6.13(\mathrm{~s}, 1 \mathrm{H})$, 5.60 (dd, 1H, J $8.2 \mathrm{~Hz}, J_{2} 5.5 \mathrm{~Hz}$ ), 3.78 (d, 1H, J 21,0 Hz), 3.48 (d, 1H, J21.5 Hz), 1.79 (m, 1H), 1.54 (m, 1H), 1.23-1.49 $(\mathrm{m}, 10 \mathrm{H}), 0.90$ (t, 3H, $J 7 \mathrm{~Hz}) .{ }^{13} \mathrm{C}$ NMR $\left(75 \mathrm{MHz}, \mathrm{CD}_{3} \mathrm{OD}\right)$ : $\delta 169.1(\mathrm{C}), 159.6(\mathrm{C}), 155.3(\mathrm{C}), 132.8(\mathrm{C}), 114.0(\mathrm{C}), 106.1$ $(\mathrm{CH}), 102.1(\mathrm{CH}), 80.1(\mathrm{CH}), 36.8\left(\mathrm{CH}_{2}\right), 32.7\left(\mathrm{CH}_{2}\right), 30.8$

*e-mail: adilson.beatriz@ufms.br
$\left(\mathrm{CH}_{2}\right), 30.3\left(\mathrm{CH}_{2}\right), 30.2\left(\mathrm{CH}_{2}\right), 26.7\left(\mathrm{CH}_{2}\right), 23.7\left(\mathrm{CH}_{2}\right), 14.4$ $\left(\mathrm{CH}_{3}\right)$. IR $(\mathrm{KBr}) v_{\text {max }} / \mathrm{cm}^{-1}: 3375,2923,2854,1735,1716$, 1650, 1458, 1091. MS (m/z): $278\left(\mathrm{M}^{\bullet+}\right), 261,233,219,209$, 181 (base peak), 153, 123, 97, 81, 69, 45 .

\section{3,5-Dimethoxy-2-octanoylphenylacetic acid (8)}

${ }^{1} \mathrm{H}$ NMR $\left(\mathrm{CDCl}_{3}\right): \delta 6.50(\mathrm{~d}, 1 \mathrm{H}, J 2 \mathrm{~Hz}), 6.43(\mathrm{~d}, 1 \mathrm{H}$, $J 2 \mathrm{~Hz}), 3.85$ (s, 3H), $3.83(\mathrm{~s}, 3 \mathrm{H}), 3.53(\mathrm{~s}, 2 \mathrm{H}), 2.93(\mathrm{t}$, $2 \mathrm{H}, J 7 \mathrm{~Hz}), 1.66$ (qt, 2H, J $7 \mathrm{~Hz}), 1.23-1.32(\mathrm{~m}, 8 \mathrm{H}), 0.88$ $(\mathrm{t}, 3 \mathrm{H}, J 7 \mathrm{~Hz}) \cdot{ }^{13} \mathrm{C} \mathrm{NMR}\left(\mathrm{CDCl}_{3}\right): \delta 210.1(\mathrm{C}), 172.3(\mathrm{C})$, 162.6(C), $159.9(\mathrm{C}), 135.4(\mathrm{C}), 122.7(\mathrm{C}), 107.5(\mathrm{CH}), 98.2$ (CH), $55.7\left(\mathrm{CH}_{3}\right), 55.5\left(\mathrm{CH}_{3}\right), 44.2\left(\mathrm{CH}_{2}\right), 41.5\left(\mathrm{CH}_{2}\right), 31.6$ $\left(\mathrm{CH}_{2}\right), 29.3\left(\mathrm{CH}_{2}\right), 29.0\left(\mathrm{CH}_{2}\right), 24.7\left(\mathrm{CH}_{2}\right), 22.5\left(\mathrm{CH}_{2}\right), 14.1$ $\left(\mathrm{CH}_{3}\right)$. IR (KBr) $v_{\max } / \mathrm{cm}^{-1}: 3002,2950,2918,2850,1706$, 1652, 1598, 1456, 1313, 1161, 1087, 846. MS (m/z): 320, 261, 238, 224, 223 (base peak), 196, 195, 178, 165, 149, 135, 120, 107, 91, 77, 69, 55, 41, 27.

\section{Compound 10}

${ }^{1} \mathrm{H}$ NMR (CD $\left.\mathrm{OD}\right): \delta 13.35(\mathrm{~s}, 1 \mathrm{H}), 6.50(\mathrm{~d}, 1 \mathrm{H}$, $J 2 \mathrm{~Hz}), 6.30$ (d, 1H, J $2 \mathrm{~Hz}), 3.87$ (s, 3H), 3.56 (s, 2H), 2.99 (t, 2H, J 7 Hz), 1.59 (m, 2H), 1.25-1.32 (m, 8H), 0.87 $(\mathrm{t}, 3 \mathrm{H}, J 7 \mathrm{~Hz}) .{ }^{13} \mathrm{C} \mathrm{NMR}\left(\mathrm{CD}_{3} \mathrm{OD}\right): \delta 207.6(\mathrm{C}), 175,9(\mathrm{C})$, 164,7,0 (C), 161.3 (C), 141.4 (C), $111.8(\mathrm{C}), 111.2(\mathrm{CH})$, $102.5(\mathrm{CH}), 55.7\left(\mathrm{CH}_{3}\right), 44.9\left(\mathrm{CH}_{2}\right), 41,3\left(\mathrm{CH}_{2}\right), 31.7\left(\mathrm{CH}_{2}\right)$, $29.4\left(\mathrm{CH}_{2}\right), 29.2\left(\mathrm{CH}_{2}\right), 24.5\left(\mathrm{CH}_{2}\right), 22.6\left(\mathrm{CH}_{2}\right), 14.1\left(\mathrm{CH}_{3}\right)$. IR (KBr) $v_{\text {max }} / \mathrm{cm}^{-1}: 3407,2948,2925,1627,1596,1577$, $1421,1392,1230,1105$.

\section{3,5-Dihydroxy-4-octanoylbenzoic acid (11)}

${ }^{1} \mathrm{H}$ NMR (CD $\left.\mathrm{OD}\right): \delta 6.31(\mathrm{~s}, 2 \mathrm{H}), 3.46(\mathrm{~s}, 2 \mathrm{H}), 3.10(\mathrm{t}$, $2 \mathrm{H}, J 7 \mathrm{~Hz}$ ), 1.67 (qt, 2H, J $7 \mathrm{~Hz}), 1.25-1.38$ (m, 8H), 0.91 (t, 3H, J 7 Hz). $\left.{ }^{13} \mathrm{C} \mathrm{NMR} \mathrm{(CD} \mathrm{OD}\right): \delta 209.3(\mathrm{C}), 174.4(\mathrm{C})$, $163.4(\mathrm{C}), 144.6(\mathrm{C}), 110.1(\mathrm{C}), 109.4(\mathrm{CH}), 44.4\left(\mathrm{CH}_{2}\right)$, $42.1\left(\mathrm{CH}_{2}\right), 32.9\left(\mathrm{CH}_{2}\right), 30.5\left(\mathrm{CH}_{2}\right), 30.3\left(\mathrm{CH}_{2}\right), 25.8\left(\mathrm{CH}_{2}\right)$, $23.7\left(\mathrm{CH}_{2}\right), 14.4\left(\mathrm{CH}_{3}\right)$. IR $(\mathrm{KBr}) v_{\max } / \mathrm{cm}^{-1}: 3409,3249$, 2952, 2921, 2852, 1714, 1637, 1581, 1429, 1232, 1066. 


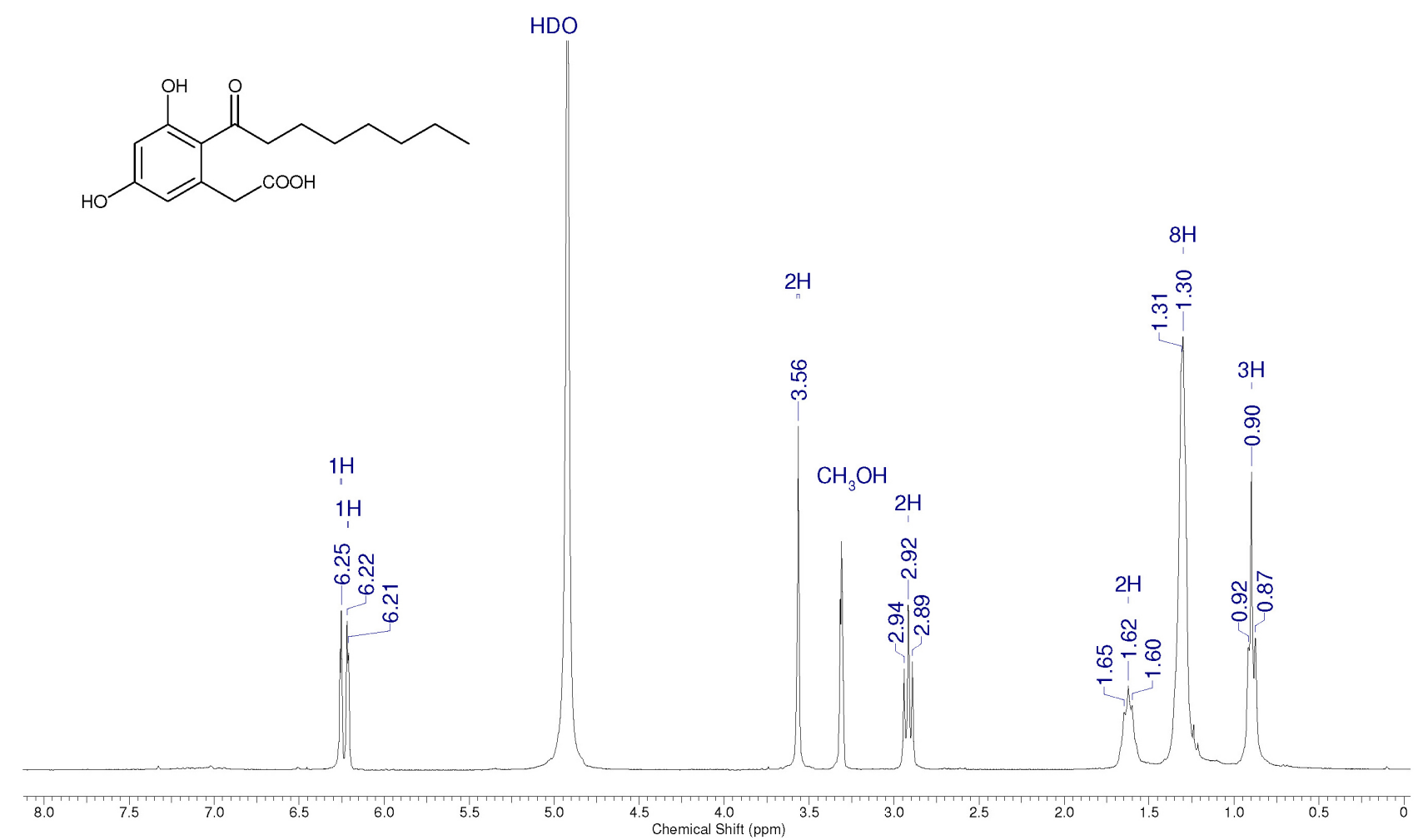

Figure S1. ${ }^{1} \mathrm{H}$ NMR spectrum for cytosporone A (1) (300 MHz, $\left.\mathrm{CD}_{3} \mathrm{OD}\right)$.

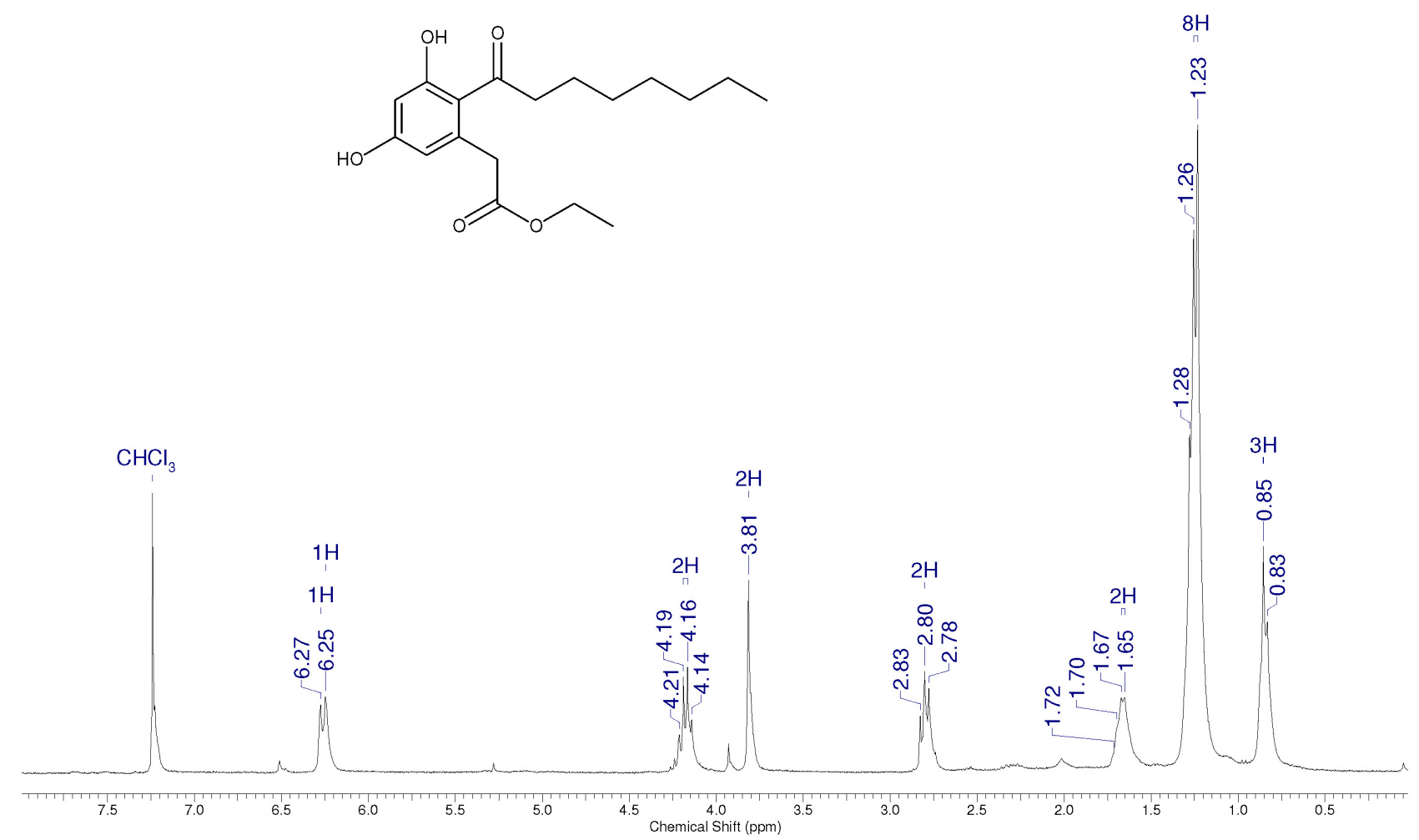

Figure S2. 'H NMR spectrum for cytosporone B (2) (300 MHz, $\mathrm{CDCl}_{3}$ ). 


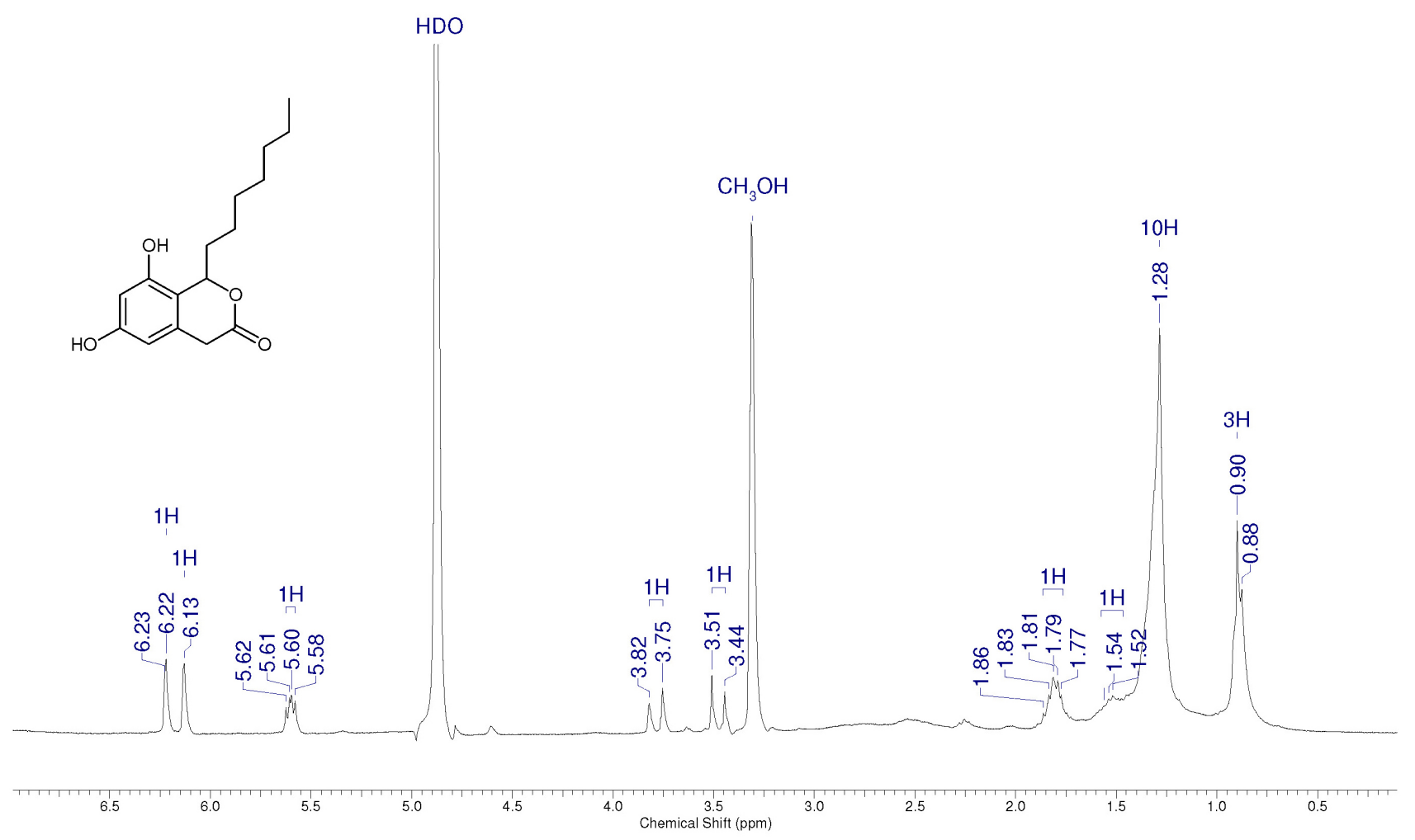

Figure S3. ${ }^{1} \mathrm{H}$ NMR spectrum for cytosporone C (3) (300 MHz, $\left.\mathrm{CD}_{3} \mathrm{OD}\right)$.

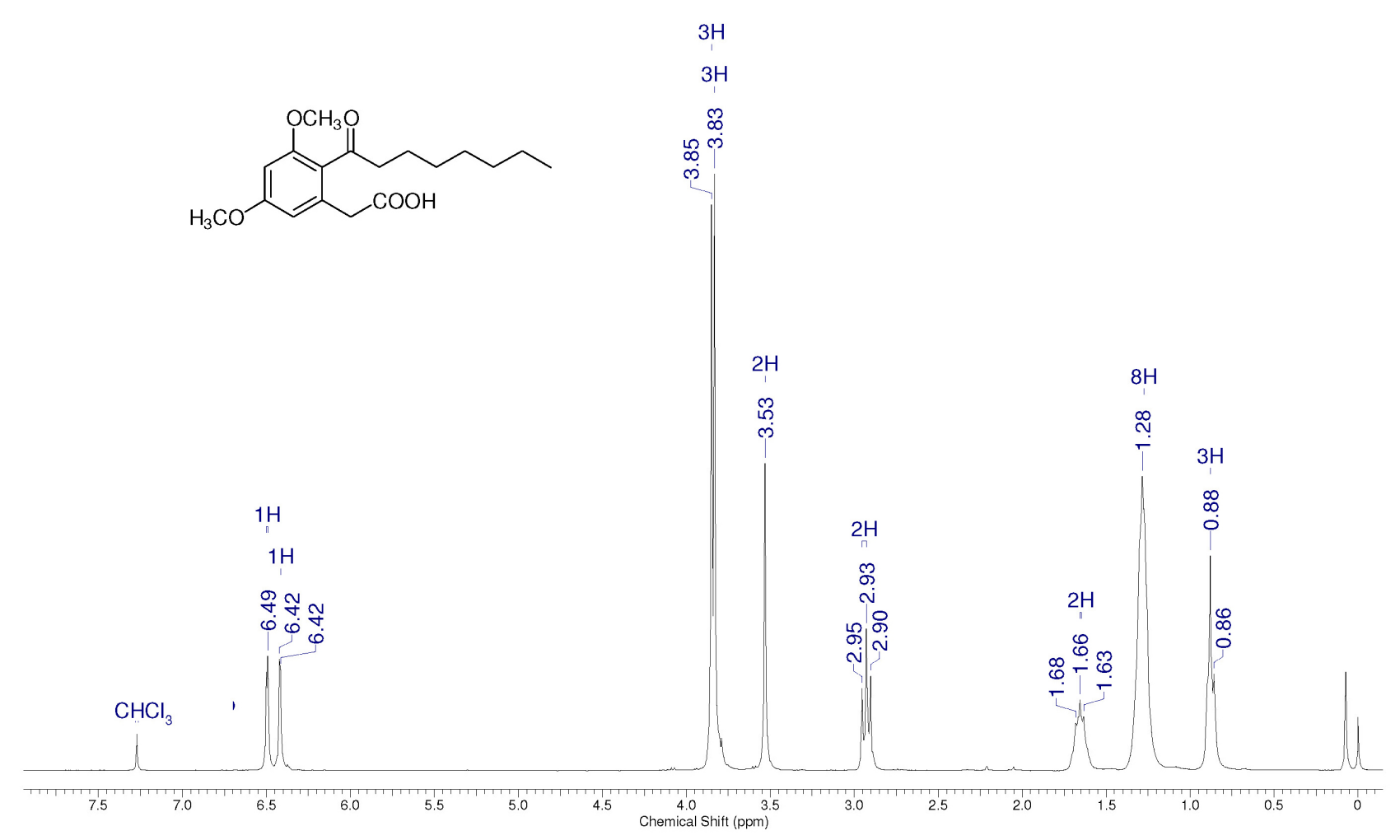

Figure S4. ${ }^{1} \mathrm{H}$ NMR spectrum for compound $8\left(300 \mathrm{MHz}, \mathrm{CDCl}_{3}\right)$. 


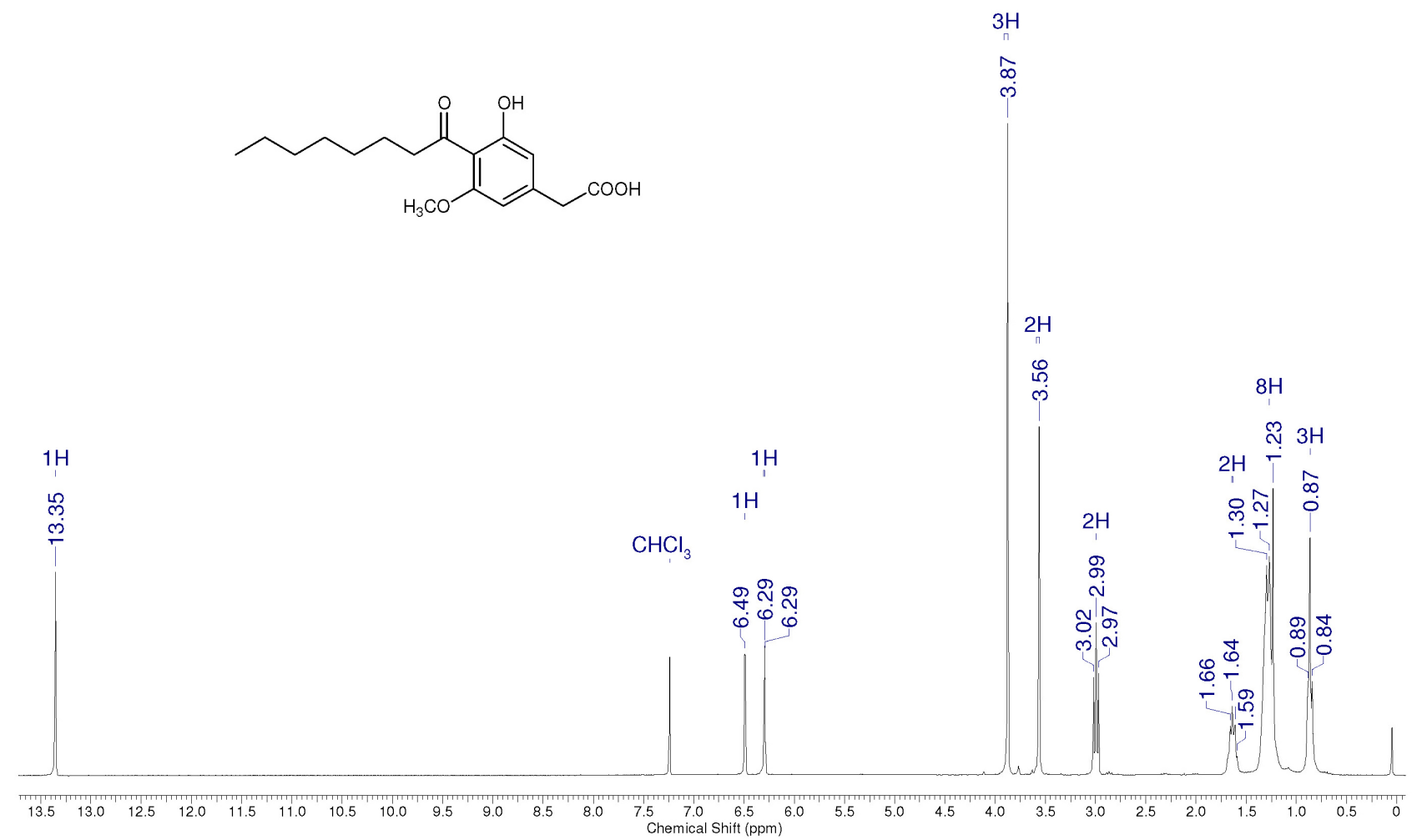

Figure S5. ${ }^{~} \mathrm{H}$ NMR spectrum for compound $10\left(300 \mathrm{MHz}, \mathrm{CDCl}_{3}\right)$.

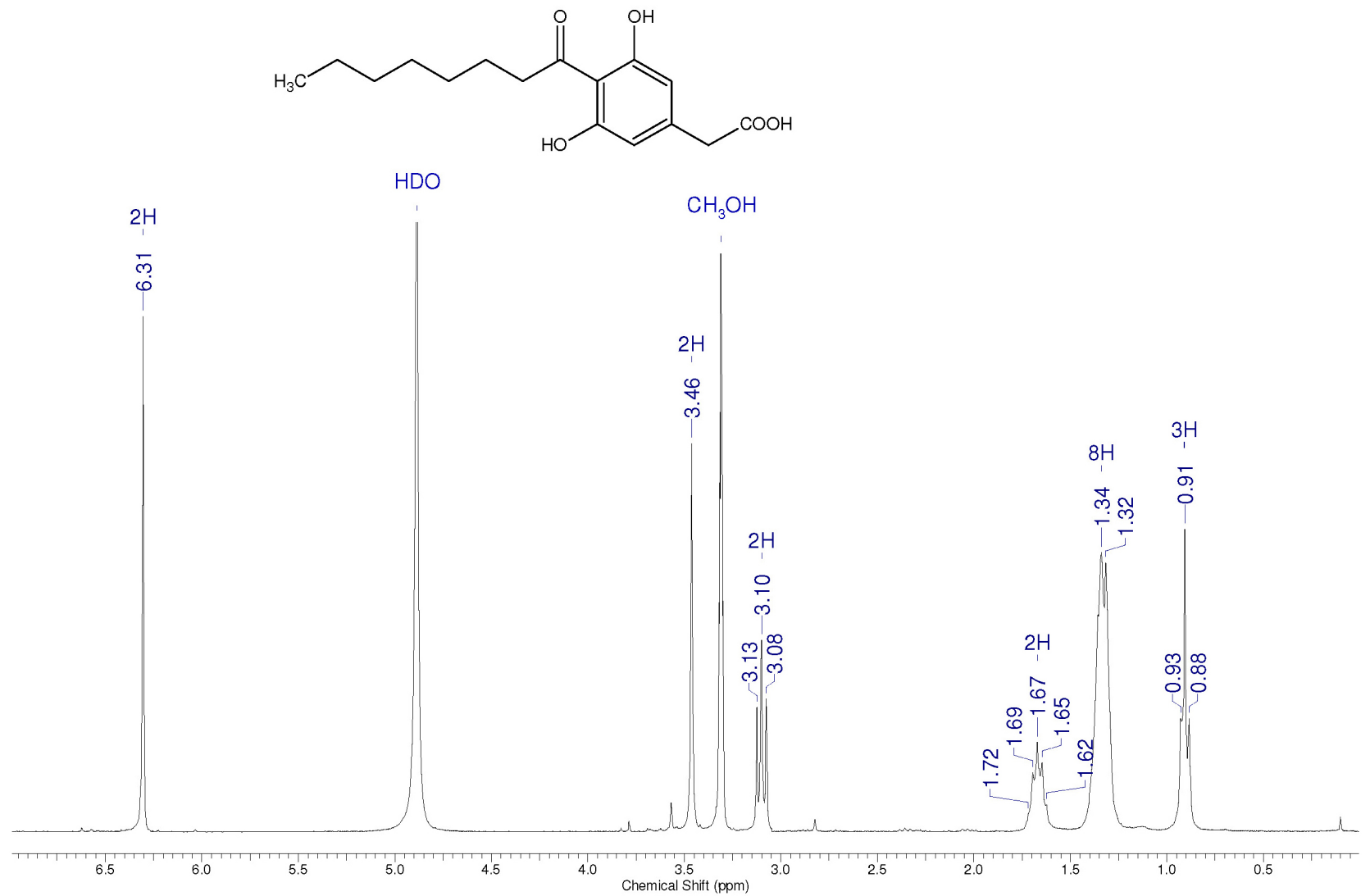

Figure S6. ${ }^{1} \mathrm{H}$ NMR spectrum for compound $11\left(300 \mathrm{MHz}, \mathrm{CD}_{3} \mathrm{OD}\right)$. 


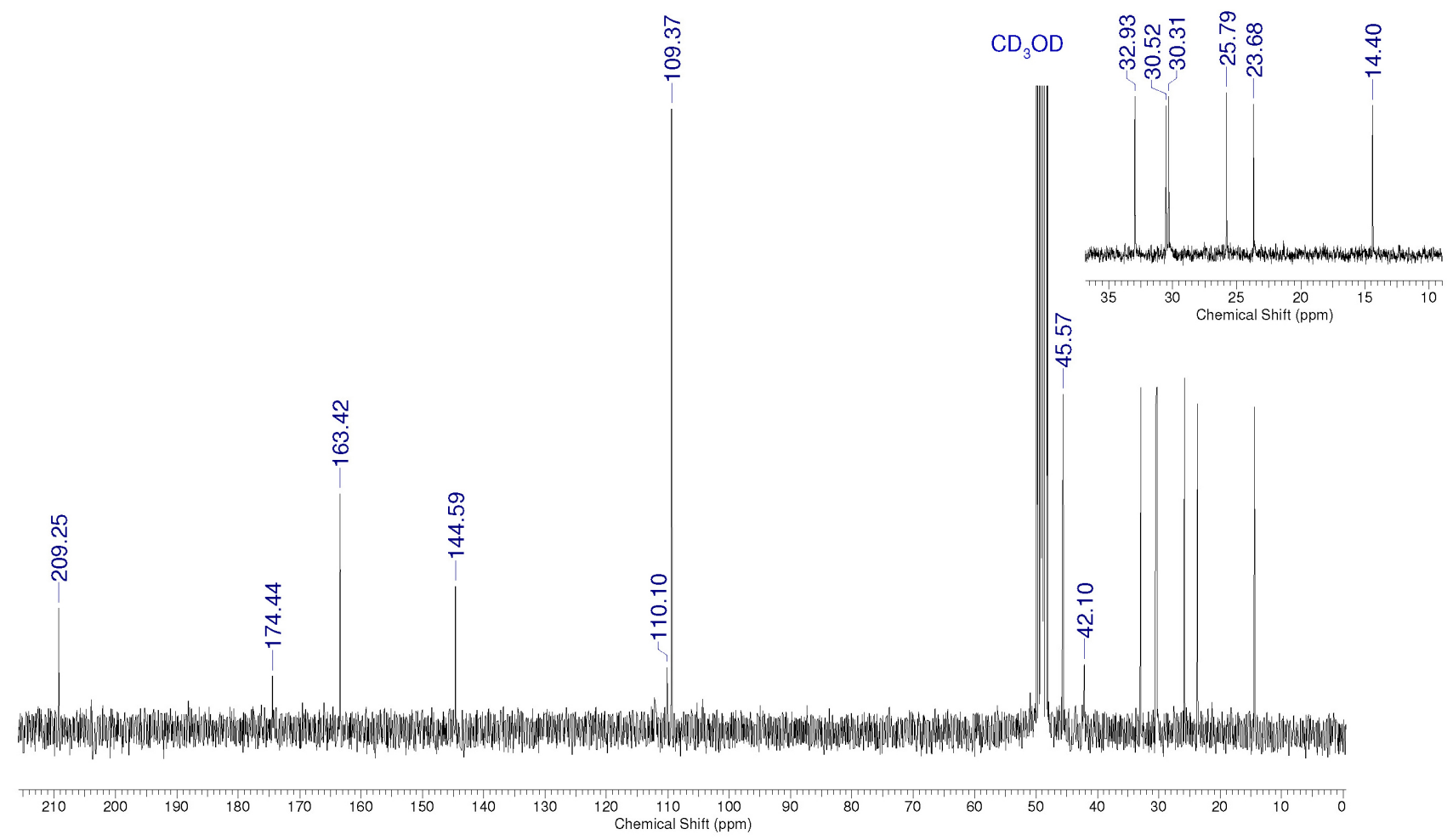

Figure S7. ${ }^{13} \mathrm{C}$ NMR spectrum for compound $11\left(75 \mathrm{MHz}, \mathrm{CD}_{3} \mathrm{OD}\right)$.

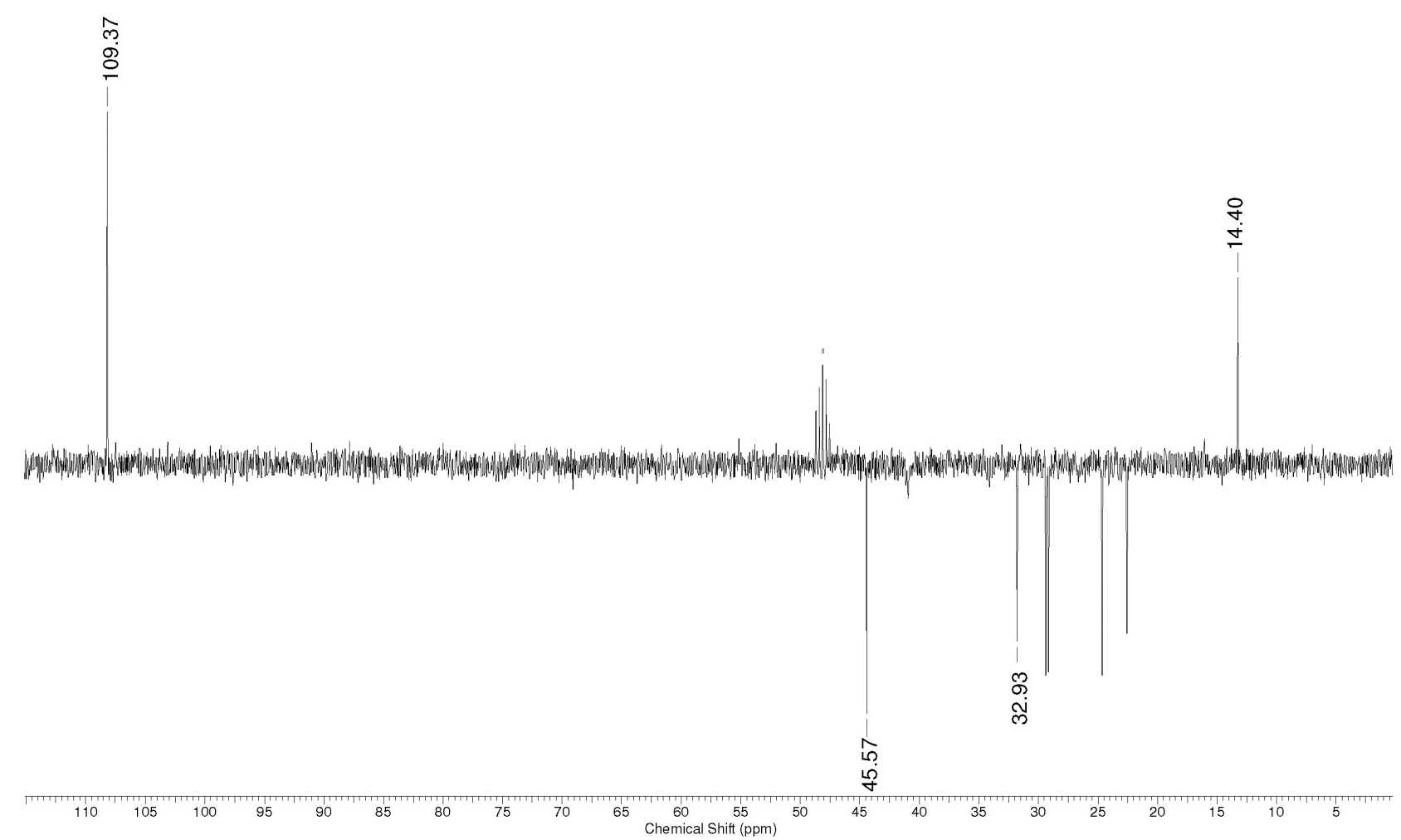

Figure S8. DEPT-135 spectrum for compound $\mathbf{1 1}\left(\mathrm{CD}_{3} \mathrm{OD}\right)$. 